\title{
Rudiments of the Periphery in the Structure of a Modern City: The Case of Krasnoyarsk
}

\author{
Elena Logunova ${ }^{1, *}$ \\ ${ }^{1}$ Department of Urban Design and Planning, Siberian Federal University, Krasnoyarsk, Russia \\ *Corresponding author. Email: el.lgnv@yandex.ru
}

\begin{abstract}
The concept of urban fringe belts was formulated in studies of the cities structure development in the first third of the 20th century. According to this concept, the peripheral territories of the past periods of the city's development preserve their former spatial and functional characteristics in modern city structure. The fringe belt features determine their preservation in the city structure for a long time during the historical city growth.

In the study the process and conditions of the continuity of fragments of the Krasnoyarsk fringe belt of the late 19th - mid-20th centuries are considered as well as its trace in the modern city plan using morphological analysis. This approach enables to establish the physical composition of the existing urban fabric, to suggest the prospects and potential of its development.
\end{abstract}

Keywords: Urban fringe belt, Fixation line, Urban morphology, City structure, Morphological continuity.

\section{INTRODUCTION}

The growth and functioning of diverse cities are marked by a common pattern - a cyclical formation of urban fabric modified by external factors, which is confirmed in the foreign and domestic studies of the second half of the 20 century [1], [2]. In each subsequent phase of the city' evolution the priority is to ensure urban continuity. The continuity of urban development involves the preservation and translation of the sustainable functional and planning structure of the city [3]. In this regard, it becomes paramount to understand the logic behind formation of static elements in the urban fabric.

The theory of urban morphology singles out fringe belts as a distinctive obvious structural part of a city. Fringe belts emerge spontaneously in the course of a city's evolution on the periphery of urban development. As they grow and expand, fringe belts are included in the city plan and remain a characteristic trace of previous eras [4], [5].

The study of the formation of stable structural elements of the city, including fringe belts, their features and influence on the subsequent stages of the city development can explain the physical composition of the existing urban fabric and more reasonably and realistically predict the possibilities of its development and reorganization.

In the article the conditions of fringe belt formation and transformation, specific characteristics, as well as the factors that influenced its preservation in the modern city plan are studied using the example of the north-eastern fringe belt of Krasnoyarsk.

\section{FRINGE-BELT AND FIXATION LINE}

The appearance of fringe belt is closely associated with the presence of a barrier - a fixation line - which hinders the development of a city at a certain point in history $[6,7]$. Fixation line can be a physical object of natural and anthropogenic origin, as well as an intangible - administrative and legal regulations (e.g., administrative boundaries of the city). The fixation line of urban development provokes the chaotic emergence of mixed land use on its periphery. The fringe belts are characterized by the types of land use that are not rational to place in the urban area: warehouses, industrial, transport facilities, cemeteries, low-rise residential buildings, as well as large socially important facilities (educational and health care institutions, 
etc.), for which there is no appropriate territory in the densely built-up city. The spontaneous emergence of fringe belts affects their physical characteristics: these territories are characterized by a tangled street and road network, complex system of boundaries, large number of open spaces and low building density.

During the extensive growth stage, urban development crosses the fixation line and "leapfrogged" the chaotic land use of the former urban periphery, incorporating it into the city limits. Functional and morphological heterogeneity complicate the planned development and structuring of these areas. In addition, the evolutionary and functional peculiarity of fringe belts along with low-value objects contribute to the preservation of architectural monuments and valuable landscapes in their structure, which requires tailored approach to their reorganization [8].

Modern researchers confirm the universality of the formation of fringe belts in cities of different cultures and depths of history [9].

\section{THE FRINGE BELTS OF KRASNOYARSK}

In the late 19th century, Krasnoyarsk city was a compact planning structure on the lower floodplain terrace of the left bank of the Yenisei River. In this period, the city plan featured two fringe belts with distinct fixation lines. On the north of the urban area the first fringe belt of the late 17th - mid 18th centuries was formed at the base of Karaulnaya Mountain slope as a topographic fixation line. In the west, the fringe belt of the second half of XIX century emerged at the foot of Afontovaya Mountain. Then, the tracing of a railroad along the slope fixated an extensive mixed land use.

The comprehensive plan of 1898 presupposed territorial development of the city to the west, and planning documents of the first half of the 20 century provided for active development of the right bank of the Yenisei river. The area north-east of Krasnoyarsk on the upper floodplain terrace was not considered promising for urban development [10]. Thus, the administrative boundary of Krasnoyarsk and the project plans limited the growth of the city in the northeastern direction and provoked spontaneous development in the study area.

Comparative analysis of morphological structure development of the fringe belt was carried out on the basis of archival materials, the surviving descriptions of the city of the late 19th - mid 20th centuries, comparison of fixation plans of 1748 , 1894, 1902, 1906 and city development plans of 1828, 1898, 1924, 1934. The research also considered, morphological characteristics (street and road network and survey sections), property and legal status of land plots and the evolution of land use types in the city development.

\section{THE FORMATION AND TRANSFORMATION OF THE NORTHEASTERN FRINGE BELT}

According to the fixation plan of 1894 , the northeastern edge of the urban development was only occupied by Troitskoye cemetery. One of the impulses for the development of the north-eastern outskirts in the first decade of the 20th century was the urgent need to locate a military camp in connection with the relocation of the 31st East Siberian Rifle Regiment to Krasnoyarsk. In the structure of the city there was already a smaller military town, consisting of residential barracks, outbuildings, and Platz-Parade square for combat training. It appeared earlier on the western outskirts of the city in the second half of the 19th century, and later joined the city limits. To accommodate the military units the City Duma allocated an area of about 100 hectares on the periphery behind the Trinity Cemetery along Yeniseisky Trakt, where all the military facilities were moved. In this case, the process of relocation can be observed - the transfer of land uses from the previously formed fringe belt included in the urban development, to the modern periphery of the city [11]. On the territory of the old military town, a radio factory was later established, and Platz-Parade square was transformed into the city's Red Square.

By the 1920s, within the new military town there appeared a group of buildings consisting of soldiers' barracks, officer's houses, warehouses, the Alexander Nevsky Regimental Church and related structures. By this time, near the city cemetery, there emerged a city Hippodrome (1924) and a warehouse area.

During the Great Patriotic War, one of the parts of the north-eastern outskirts was used as an airfield. In the postwar period, this function was fixed: the airfield was converted to serve the civil aviation. In 1954, there appear terminal buildings, hangars and other transport facilities. 
In the 1960s, the area in the northeast along the left bank of the Yenisei became a priority for urban development, which provoked transformations on the periphery.

Aerial photography of Krasnoyarsk in 1967 allowed to establish the four-part structure of the fringe belt, which was formed by this time ("Figure $1 ")$. The first fragment showed the increase of territory and development area of the military town: within its boundaries there was a functioning system of military institutions with adjoining areas. Moreover, in the 1960s, the perimeter of the military town was fenced, which led not only to the functional, but also to the physical separation of the territory. On the plots adjacent to the military camp there emerged off-plan private and utility buildings. On the second fragment there was a section of the city airport with associated transport infrastructure. The third fragment, which included the city Hippodrome and Trinity Cemetery, featured storage facilities and private development. The fourth fragment to the west of the airport was represented by several storage and manufacturing facilities. In addition, to the east of the military town, the aerial photo showed the appearance of apartment buildings on the bank of the Yenisei river. Consequently, by the end of the 1960s, the urban development overstepped the land use of the fringe belt.

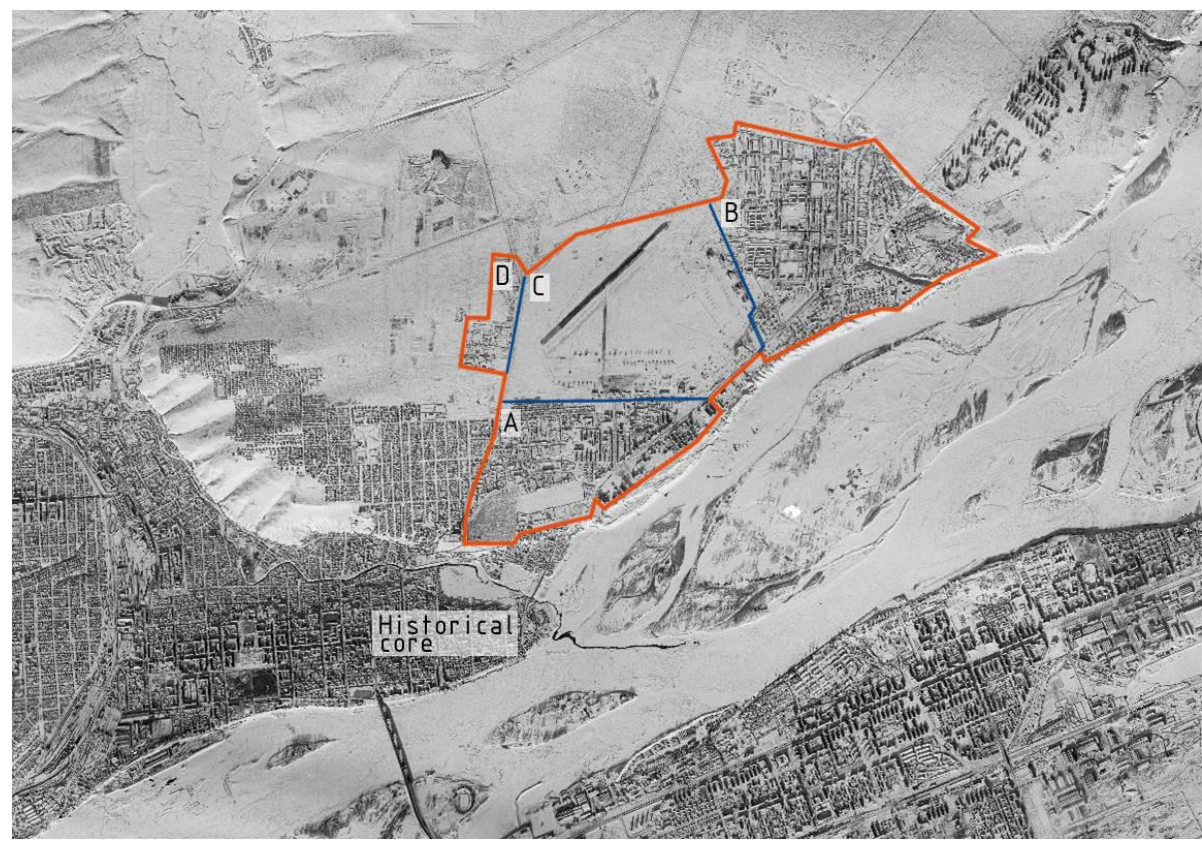

Figure 1 Fringe belt of the late 19th - mid-20th centuries (in red) in relation to the historical core of Krasnoyarsk in 1967. Boundaries of four-part fringe-belt structure (in blue): fragment A (which included Troitskoye cemetery and city Hippodrome), fragment B (which included military town), fragment C (which included city airport), fragment D (which included storage and manufacturing facilities)

According to the design plans, it was suggested to take the airfield outside the borders of Krasnoyarsk within a short period of time. Yet, by the 1970s, the airport continued to operate in the same place despite the rapid sprawl of residential development in the adjacent areas along the bank of the Yenisei.

As morphological analysis showed the first radical functional and structural changes of the fringe belt occured only by the end of the 1980s. The territorial prospects of development were lost for the Airport, and by 1989 it was transferred source: Krasnoyarsk aerial photography in 1967, maps.kosmosnimki.ru.

outside Krasnoyarsk. Nevertheless, the layout of the new residential area that emerged on the site of the airport retains the character of the pre-existing planning structure and type of land use. The pattern of residential streets inherited the directions of the runways ("Figure 2"). One of the hangars, which remained apart from the built-up area and was not functionally adapted to the new conditions, existed until 2019. After the transfer from federal property to municipal property it was dismantled, until then being a characteristic trace of the territory's previous purpose. The air terminal building and the adjoining site became part of the urban fabric of the 
new urban areas, reorganized into the city bus terminal. In 2020, the air terminal building was

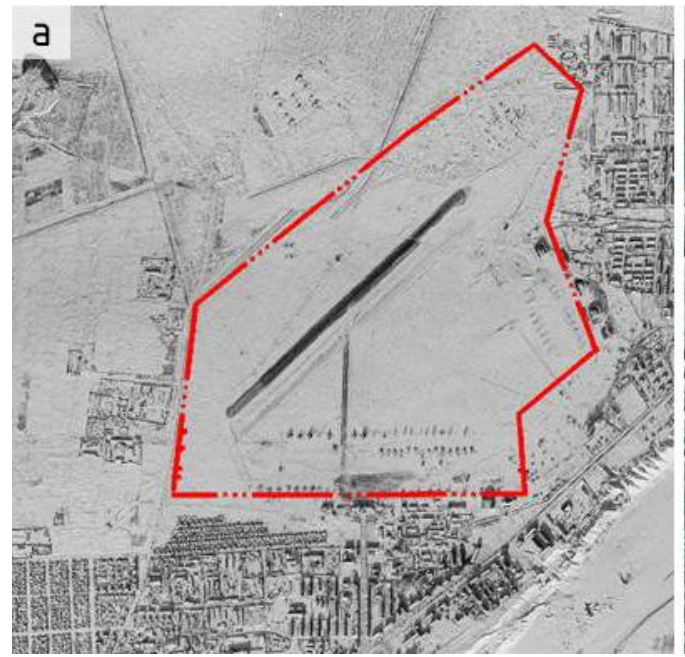

included in the cultural heritage list of regional importance.

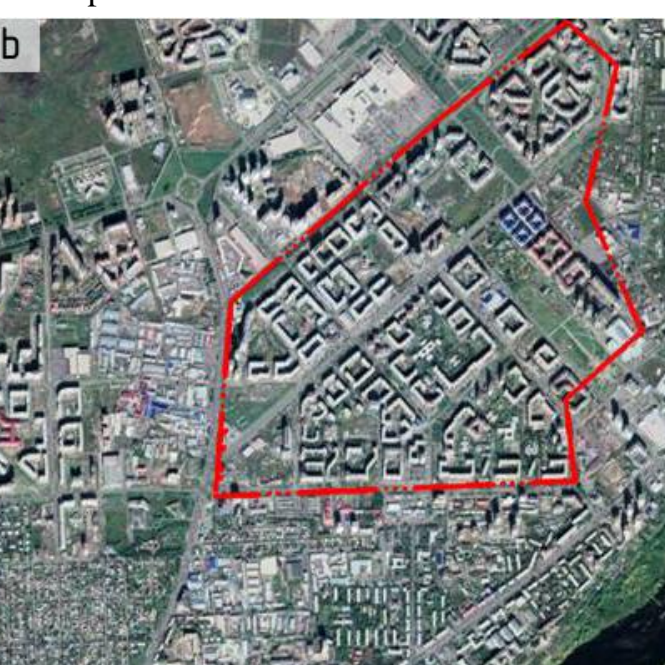

Figure 2 Fragment C alienation process: (a) city airport and runway pattern in 1967, (b) residential area and street pattern in 2020 .

A radical change of function in the fringe belt in the theory of urban morphology is denoted by the process of alienation - in this case, the total reorganization of the periphery and the transfer of peripheral land uses to residential development [12]. Nevertheless, with radical changes in the fringe, the inheritance of such stable morphological features as the street and road network patterns is not excluded, which is confirmed by this example.

In the 1970s, the fringe belt fragment with a section of the military town was included into the developing residential areas. By the early 2000s, this fragment of the fringe belt became surrounded by residential development. The peculiarities of the military town functioning as well as the availability of land resources for the development of residential areas in the 20th-21st centuries led to its conservation and preservation in the modern plan of the city.

The configuration of the fringe belt predetermined the distinctive tracing of urban highways, which ran along the border of the territory. The military facilities within the military town continued to function actively until the end of the socialist period, thereby isolating the area from the surrounding urban development. In the postsocialist period, federal ownership of the military town was established but most of its former source: Krasnoyarsk aerial photography of 1967, maps.kosmosnimki.ru, Google Earth Image.

functions were gradually lost. At the moment, in addition to the military unit, military town hosts Krasnoyarsk cadet corps named after A. I. Lebed' and the Krasnoyarsk Mariinsky Women's Gymnasium as well as the Siberian Regional Search and Rescue Unit of the Emergency Situations Ministry of Russia. Initially, the nature of the functional use, and then the form of ownership caused the isolation of the territory from the socio-economic and spatial processes and relations in the city. The loss of former functions in the isolated structure of the fringe belt exacerbated this situation and led to the degradation of the territory observed in the present time.

Comparative morphological analysis revealed that the main large-scale changes in this fragment were noted outside the military town. In the 1970s, within the residential development area along the city streets, there appeared apartment housing. Certain areas of private development away from traffic arteries on the bank of the Yenisei River are preserved to this day. Subsequent changes in this fragment were of local nature and are observed along the perimeter of the military town due to the gradual transfer of small plots of land from federal ownership to the municipality. The area also started to feature commercial functions and house large commercial centers ("Figure 3"). 

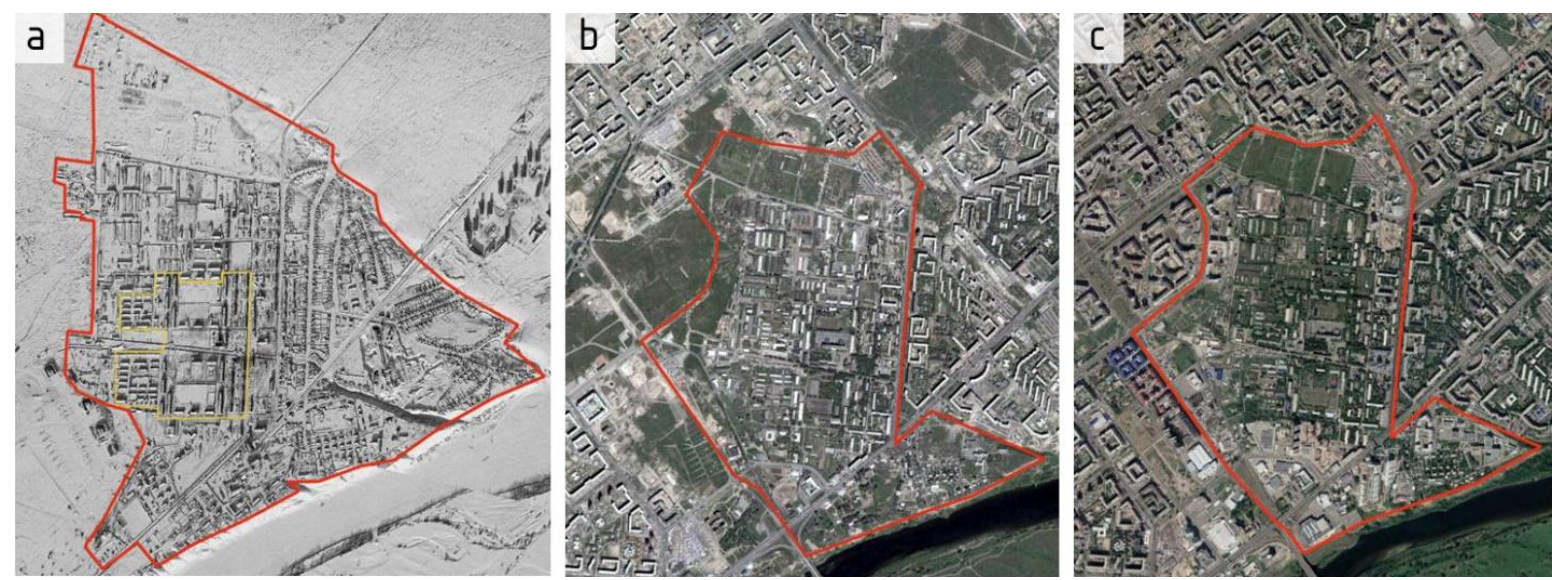

Figure 3 Fragment D transformation process: (a) morphological structure in 1967, (b) transformation by 2002, (c) - land use degradation by 2020.

The study showed the distinctive pattern of the street network and the areas of land survey of the fringe belt fragment as compared to the territories of the adjacent residential development. Due to the peculiarities of the territory, the original street and road network did not undergone significant changes over time.

The isolated functioning of the former military town allowed to keep valuable architectural objects in its structure. Buildings erected in 1905, 1917, 1919, 1937 - barracks and officers' houses, - are
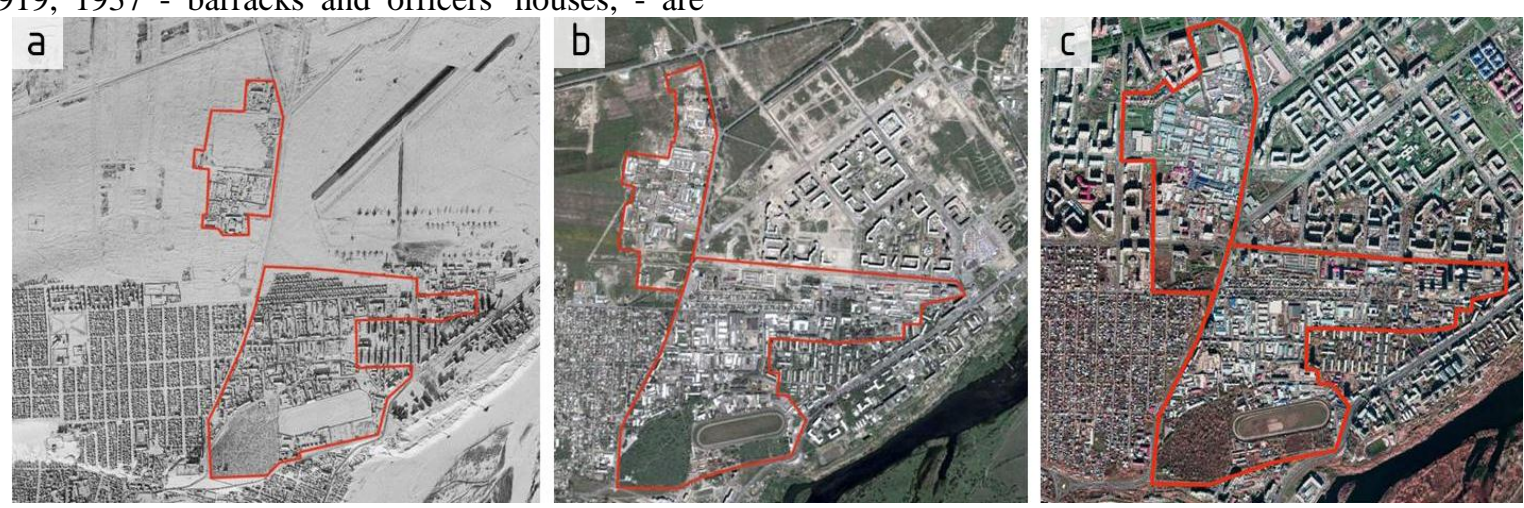

Figure 4 Fragment A and fragment D forming process: (a) early structure phase in 1967, (b) and (c) consolidation fringe land use in 2002 (centre), and in 2020 (right).
Loosely traced street network, mixed functional purpose, a complex structure of land surveying and a large number of owners contribute to the consolidation of specific land use within urban areas. A system of in-demand warehouse and commercial enterprises ensures the economic sustainability of these areas. The morphological structure of the fringe belt fragments is distinguished from the adjacent residential areas by made in "brick style", typical for Russian architecture of the turn of 19th-20th centuries and at the moment are used as dwelling houses.

From the second half of the 20th century to the present day, the third and fourth fragments of the fringe belt have seen an increase in the number and density of utility and commercial objects. By the end of the first decade of the 21 st century, vast areas of the fragments were included in residential development ("Figure 4"). source: Krasnoyarsk aerial photography of 1967, maps.kosmosnimki.ru, Google Earth Image.

a number of physical parameters, such as the size and shape of survey plots, location and configuration of buildings, and density of development.

\section{CONCLUSION}

The unplanned, spontaneous emergence of land use on the periphery of urbanized area in specific 
historical conditions may remain a visible trace for a long time when the territory of the former periphery is included in the city limits [13].

The studied northeastern fringe belt of the late 19th - mid-20th centuries is clearly distinguished in the modern city plan of Krasnoyarsk as a system of fragments of different quality, characterized by their structure and purpose. Administrative boundary and prospects of territorial development of the city triggered the belt's formation. Due to the intangible and hence variable and impermanent nature of the fixation line, its trace did not remain in the fabric of the city, but affected the open configuration of the fringe belt and its one-sided location relative to the city.

After the loss of the fixation line and its inclusion into the city limits, there was an involuntary inheritance of the primary functional and spatial characteristics of the fringe belt fragments. As a result, previously peripheral areas became a structural part of the city plan. A set of parameters, such as the pattern of street and road network, structure and efficiency of land use, and form of ownership had a particular influence on the sustainability of the sites and the degree of continuity of the fringe belt.

As demonstrated by the example of a site with the city airport, the homogeneous property and legal status of a large fragment of the fringe belt contributed to its radical transformation. Nevertheless, such a stable morphological element as street and road network was preserved in the planning of the area. The nature of use allowed the fragment of the fringe belt with the military town to operate in the structure of residential development over a long period. The loss of functional purpose in conjunction with the property and legal status of the site (federal form of ownership) excluded the area from the socio-economic processes of the city.

At the moment, vast areas of fringe belts with extensive land uses conceal a great potential and resource for the transformation of the city planning structure to meet modern requirements. Nevertheless, they still remain a rudiment in the city plan due to the lack of mechanisms for their comprehensive and interrelated reformation.

\section{AUTHOR'S CONTRIBUTIONS}

This paper is independently completed by Elena Logunova.

\section{ACKNOWLEDGMENTS}

This research was funded by Krasnoyarsk Regional Fund of Science. The author is most grateful for valuable advices provided by Irina Kukina.

\section{REFERENCES}

[1] D. Hazar, A.Kubat, Fringe belts in the process of urban planning and design: Comparative analyses of Istanbul and Barcelona, ITU A|Z, Journal of Faculty of Architecture, Vol.12, № 1, 2015. pp. 53-65.

[2] A.E. Gutnov, The Evolution of Urban Planning (Evoliutsiia gradostroitel'stva), Stroiizdat, Moscow, 1984. 256 p. [in Russian].

[3] D. B. Veretennikov, State of town-planning of continuity in Russia (Sostoyanie problemy gradostroitelnoi preemstvennosti v Rossii), Bulletin of SamGASU, Town Planning and Architecture, № 1 (14), 2014, pp. 31-35 [in Russian].

[4] J. W. R. Whitehand, Urban fringe belts development of an idea, Planning perspective, № $3, \quad 1988$, pp. 47-58. $\mathrm{DOI}$ : $10.1080 / 02665438808725651$

[5] H. Louis, W. Pauzer, Die geographische Gliedering von Gross-Berlin, Landerkundliche Forschung, Engelhorn, Stuttgart, 1936. pp.146-171.

[6] M.R.G. Conzen, Alnwick, Northumberland: A Study in Town-Plan Analysis, Institute of British Geographers, London, 1969, 139 p. DOI: $10.1177 / 0309132509334948$

[7] H. Carter, S. Wheatley, Fixation Lines and Fringe Belts, Land Uses and Social Areas: Nineteenth-Century Change in the Small Town, Transactions of the Institute of British Geographers, Vol. 4, No. 2, The Royal Geographical Society (with the Institute of British Geographers), 1979, pp. 214-238. DOI: $10.2307 / 622036$

[8] M.P. Conzen, J. W. R. Whitehand, K. Gu, Comparing Traditional Urban Form in China and Europe: A Fringe-Belt Approach, Urban Geography, № 33, 2012, pp 22-45.

[9] V. Oliveira, Urban Morphology. An Introduction to the Study of the Physical Form 
of Cities, Springer, 2016, 192 p. DOI: 10.1007/978-3-319-32083-0

[10] V. T. Gorbachev, N. N. Kradin, N. P. Kradin, V. I. Krushlinskii, T. M. Stepanskaya, V. I. Tsarev. Urban planning of Siberia (Gradostroitelstvo Sibiri), Scientific Research Institute of Theory and History of Architecture and Urban Planning (NIITIAG), Kolo, St. Petersburg, 2011, 783 p. [in Russian].

[11] Ibid.

[12] V. Oliveira, Urban Morphology. An Introduction to the Study of the Physical Form of Cities, Springer, 2016, 192 p. DOI: 10.1007/978-3-319-32083-0

[13] V. Oliveira, J.W.R. Whitehand and the Historico-geographical Approach to Urban Morphology, Springer, 2019, 138 p. DOI: 10.1007/978-3-030-00620-4 